\title{
The efficacy of microphototherapy in vitiligo patients with localized lesions
}

\author{
Lokalize lezyonlara sahip vitiligo hastalarının tedavisinde mikrofototerapinin etkinliği
}

\section{Neslihan Yıldırım, Gül Erkin*}

Mardin Midyat State Hospital, Clinic of Dermatology, Mardin, Turkey

*Hacettepe University Faculty of Medicine, Department of Dermatology, Ankara, Turkey

\begin{abstract}
Background and Design: Vitiligo is a chronic skin disease. To reduce side effects associated with current treatment modalities, new treatment methods are required. Microphototherapy was introduced to treat vitiligo patients with a limited number of lesions (lesions affecting $<10 \%$ of the body surface area).

Materials and Methods: Our study has aimed to evaluate the efficacy of microphototherapy in vitiligo patients with localized lesions. In this unblinded and prospective study, patients were treated thrice weekly for at least 50 sessions using an MedLight CupCUBE Grimed ${ }^{\circledR}$ microphototherapy device which emits ultraviolet B spectrum with a starting dose of $150 \mathrm{~mJ} / \mathrm{cm}^{2}$ for 5 seconds and with increments of $30 \mathrm{mj} / \mathrm{cm}^{2}, 1$ second at each session. At the end of the $50^{\text {th }}$ session, 50\% reduction in Vitiligo Area Scoring Index (VASI) score was accepted as the required minimum response.

Results: Thirty-three lesions from 14 patients were treated. Treatment outcome was evaluated based on the VASI. Between $0^{\text {th }}$ and $50^{\text {th }}$ sessions, the mean VASI score in 33 lesions decreased from 2.25 to 1.79 showing $20.4 \%$ decline $(p<0.05)$. Twenty-one of 33 lesions exhibited decrease in VASI scores at the end of the $50^{\text {th }}$ session although only 11 of these 21 lesions reached the target of VASI $50 \%$ while the remaining 10 lesions did not reach the target. As a result, 11 lesions (33.3\%) reached VASI 50\% while the remaining 22 lesions (66.7\%) did not reach the target.

Conclusion: The efficacy of the MedLight CUpCUBE Grimed ${ }^{\circledR}$ microphototherapy device was poor with these starting doses, durations and increments for the treatment of patients with vitiligo who had localized lesions. Trying topical therapies initially, calculating minimal erythema dose and, thus, measuring the beginning ultraviolet doses and durations as a way to decrease the number of in-hospital sessions are feasible rather than applying this technique as the first option or alone in vitiligo patients with non-segmental and localized lesions.
\end{abstract}

Keywords: Vitiligo, phototherapy, treatment

Öz

Amaç: Vitiligo kronik bir deri hastalığıdır. Mevcut tedavi yöntemlerine bağlı oluşabilen yan etkileri azaltmak için yeni tedavi yöntemlerine ihtiyaç bulunmaktadır. Mikrofototerapi yöntemi sınırlı sayıda lezyona sahip (lezyonların vücut yüzey alanının \%10'undan azını etkilemesi) vitiligo hastalarını tedavi etmek için kullanılmaya başlamıştır.

Gereç ve Yöntem: Çalışmamız lokalize lezyonlara sahip vitiligo hastalarında mikrofototerapinin etkinliğini değerlendirmeyi hedeflemektedir. Prospektif olan ve kör olmayan bu çalışmada hastalara ultraviyole (UV) B ışını yayan MedLight CupCUBE Grimed ${ }^{\circledR}$ mikrofototerapi cihazı ile başlangıç UV dozu $150 \mathrm{~mJ} / \mathrm{cm}^{2}$ ve 5 saniye, her seansta doz artımı $30 \mathrm{mj} / \mathrm{cm}^{2}$ ve 1 saniye olacak şekilde haftada $3 \mathrm{kez}$ en az 50 seans boyunca tedavi uygulanmıştır. Vitiligo Alan Skorlama Indeksi (VASi) \%50 (VASi'de \%50 azalma) 50 seans sonunda istenilen en az yanit olarak kabul edilmiştir.

Bulgular: On dört hastaya ait 33 lezyon tedaviye alınmıștır. Tedaviye yanıtlar VASi ile değerlendirilmiștir. Otuz üç vitiligo lezyonunda tedaviyle beraber ortalama VASi 0-50. seanslar arasında 2,25'ten 1,79'a gerileyerek \%20,4 düşme göstermektedir ( $p<0,05)$. VASi değerlerinde düşüş 21 lezyonda izlenirken, 21 lezyonun ancak 11 'inde VASi \%50'den fazla düşme göstermiş ve istenilen yanıt düzeyine ulaşılmışır, kalan 10 lezyonda VASi \%50 hedefine ulaşılamamıştı. Sonuçta, $22(\% 66,7)$ lezyon hedefe ulaşamazken, $11(\% 33,3)$ lezyon istenen en az yanıt düzeyi olan VASi \%50'ye ulaşmıştır.

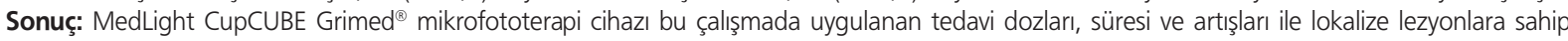
vitiligo hastalarının tedavisinde düşük düzeyde etkinliğe sahip gözükmektedir. Bu tedaviyi segmental olmayan, lokalize lezyonlara sahip vitiligo hastalarında ilk seçenek olarak veya tek başına uygulamak yerine topikal tedavilerin ilk olarak denenmesi, total seans sayısının azaltılabilmesi için minimal eritem dozunun hesaplanıp başlangıç UV doz ve sürelerinin belirlenmesi daha uygun olacaktır. Anahtar Kelimeler: Vitiligo, fototerapi, tedavi

Address for Correspondence/Yazışma Adresi: Neslihan Yildırım MD, Mardin Midyat State Hospital, Clinic of Dermatology, Mardin, Turkey Phone.: +90 5356703041 E-mail: drnesli23@hotmail.com ORCID-ID: orcid.org/0000-0002-1137-5399

Received/Geliş Tarihi: 02.12.2015 Accepted/Kabul Tarihi: 11.01.2017

c Copyright 2017 by Turkish Society of Dermatology and Venereology

Turkderm-Turkish Archives of Dermatology and Venereology published by Galenos Yayınevi. 


\section{Introduction}

Phototherapy is an important therapeutic modality commonly used for dermatological treatment. During the last two decades, there have been significant technological advancements in the field of phototherapy. A new technique referred as targeted phototherapy, concentrated phototherapy, focused phototherapy or microphototherapy, which gives directly light energy to the lesion or target, can be considered among the most important ones of such advancements. The disadvantages of conventional phototherapy devices include irradiation of unaffected areas and multiple frequent visits to clinics. It is also difficult to treat children and to treat such regions, such as genitalia and oral mucosa, with these devices. Microphototherapy devices facilitate treatment of affected regions while protecting non-affected regions ${ }^{1}$. In addition, while the technique can reduce the number of treatment sessions and total duration of the treatment ${ }^{2}$, patient satisfaction may increase due to acceleration of therapeutic response ${ }^{3}$. As opposed to conventional phototherapy, microphototherapy can be easily administered to genitalial area, oral mucosa and in children'. Several recent studies on the use of microphototherapy alone or in combination with topical drugs for the treatment of patients with vitiligo have been published ${ }^{3-5}$. The present study aimed to evaluate the efficacy of targeted ultraviolet B (UVB) phototherapy using a MedLight CupCUBE Grimed ${ }^{\circledR}$ microphototherapy device (MedLight GmbH- med.-techn. Therapiesysteme-D-32051 Herford-Germany; Grimed Ltd., İstanbul, Turkey) in the treatment of vitiligo patients with non-segmental, localized lesions.

\section{Materials and Methods}

\section{Patients}

Patients who were admitted to the university hospital clinic of dermatology were enrolled for the study. Subjects, aged $\geq 10$ years with non-segmental, localized lesions and lesions affecting $\leq 10 \%$ of the body surface area, were included in this prospective, unblinded trial. Patients were included in the study providing that they did not receive systemic therapy, such as systemic corticosteroids or immuno-suppressive agents, within the last 10 weeks and any topical agents within the last 4 weeks for the treatment of vitiligo. Exclusion criteria included pregnancy, lactation and the presence of photosensitive disorders such as porphyria and xeroderma pigmentosum. Based on these criteria, 20 patients with localized and non-segmental vitiligo lesions were included in the study, however, 6 of the patients discontinued the therapy due to several reasons. Of these, patients received the treatment for 3, 5, $6,7,7,16$ sessions, respectively. While 5 of these patients stated that they had difficulty in attending the sessions thrice a week, a patient who respected 16 sessions expressed that he discontinued the therapy since no change was recorded in his lesions after these sessions. All the patients had microphototherapy as monotherapy.

\section{Phototherapy device}

Microphototherapy was administered using a MedLight CupCUBE Grimed ${ }^{\circledR}$ device (MedLight GmbH -med.-techn. Therapiesysteme-D-32051 Herford-Germany; Grimed Ltd., İstanbul, Turkey) which uses non-excimer technology to deliver UV radiation (Figures $1 \mathrm{~A}$ and $1 \mathrm{~B}$ ). The light source was a 150-watt high-pressure spherical burner that emits both ultraviolet A (UVA) and UVB radiation.
To benefit from the device's UVA emission, a filter must be placed on the device. However, only UVB radiation was administered during the study. The spectral irradiance of the device is shown in Figure 2. The light is concentrated within the UVB wavelengths of 300-350 nm, with a peak at 311-nm. The radiation field of the system varies from 10 $\mathrm{mm}$ to $40 \mathrm{~mm}$. The UVB dose administered by the device is $30 \mathrm{~mJ}$ (milijoule) $/ \mathrm{cm}^{2}$ at a distance of $1 \mathrm{~cm}$.

\section{Treatment protocol}

All lesions were irradiated with UVB microphototherapy $1 \mathrm{~cm}$ away from the lesion. For lesions greater than $1 \mathrm{~cm}$ in diameter, the area was treated with multiple applications side by side in accordance with the lesion diameter. Regardless of skin phototype and lesion diameter, the initial UV dose was $150 \mathrm{~mJ} / \mathrm{cm}^{2}$ and the initial duration of the treatment was 5 seconds. The therapy was applied thrice weekly on non-consecutive days for at least 50 sessions in each patient with dose increments of $30 \mathrm{~mJ} / \mathrm{cm}^{2}$ and duration increments of 1 second at each session.

Phototherapy technicians administered the treatments. Just before each UV treatment session, liquid petrolatum was applied to increase UV transmission. The duration of each subsequent treatment session was increased until mild/moderate erythema was observed. When $\mathrm{mild} /$ moderate erythema developed, treatments were continued in the same way. Treatments were to be skipped if severe erythema or blistering developed. If severe erythema or bulla regressed during the subsequent treatment session, the treatment was continued using the last dose and duration; but if no regression was observed, the treatment was stopped until erythema/bulla regressed.

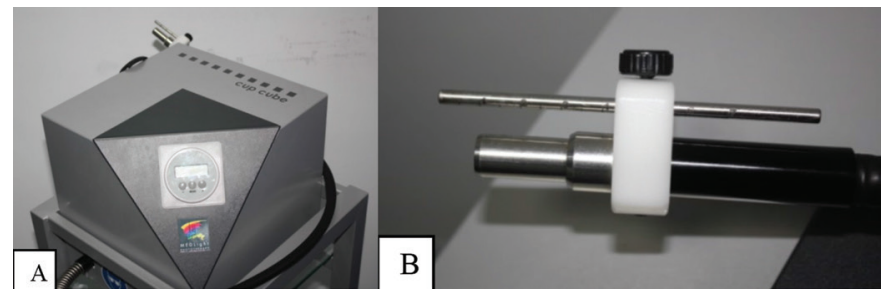

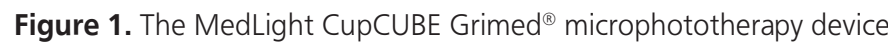
(A) and it's light-transmission cable and distance adjustment bar (B)

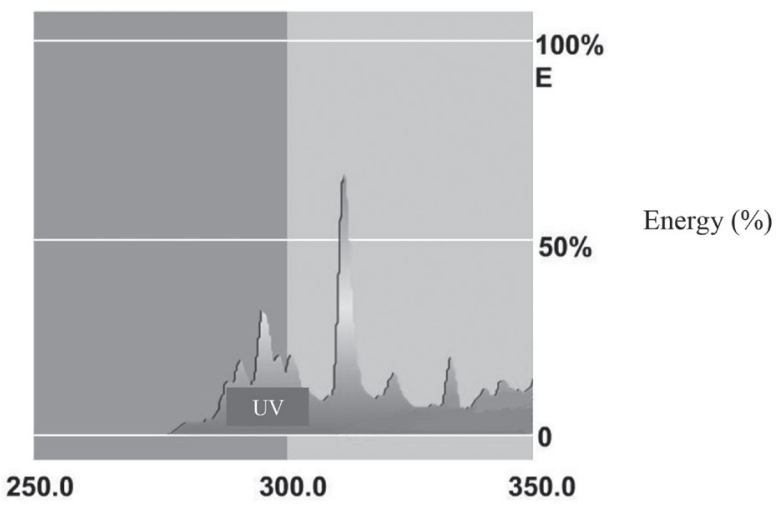

Wavelength (nm)

Figure 2. The ultraviolet spectrum of the MedLight CupCUBE Grimed ${ }^{\circledR}$ microphototherapy device 


\section{Assessment}

The Vitiligo Area Scoring Index (VASI) was used to evaluate treatment outcome $^{6}$. The VASI is a quantitative method used to standardize treatment outcomes. According to this index, the patient's body is divided into 5 areas: Hands, upper extremities (excluding hands), trunk, lower extremities (excluding the feet) and feet. The axillary and inguinal regions were included with the upper and lower extremities, respectively; whereas the buttocks were included with the lower extremities. The palms (including the volar aspects of the fingers) represent $1 \%$ of the patient's total body surface area which is used as a guide to presume the percentage of the vitiligo involvement of each body area. The extent of depigmentation within every patch was estimated to the closest of one of the following percentages: 0 , $10 \%, 25 \%, 50 \%, 75 \%, 90 \%$ or $100 \%$ (100\%: No pigment is present; 90\%: Specks of pigment are present; 75\%: The depigmented area exceeds the pigmented area; 50\%: The depigmented and pigmented areas are equal; 25\%: The pigmented area exceeds the depigmented area; $10 \%$ : Only specks of depigmentation are present). The estimated degree of depigmentation is multiplied by the percentage of vitiligo involvement of the lesion. Thus, VASI score for each lesion was calculated at baseline and at sessions 36 and 50 by the same researcher in this study (Table 1). Thus, VASI score of each lesion was calculated, and summing each VASI score of a lesion allowed us to calculate the VASI score in each patient (total VASI, ¿VASI). At the end of the $50^{\text {th }}$ session, VASI $50 \%$ (50\% reduction in VASI) was accepted as the required minimum response. If complete improvement was observed before the $50^{\text {th }}$ session, the treatment was terminated early, whereas therapy was prolonged or switched to another treatment modality if the response to treatment at the end of the $50^{\text {th }}$ session was inadequate. Treated lesions did not receive any topical or systemic therapy during the study. During the course of the treatment, the largest three diameter of each lesion was measured by using a ruler and recorded; also standardized photographs were obtained by using a CanonEOS D450 Digital Camera at baseline and at the treatment sessions 12, 24, 36 and 50 by the same investigator.

\section{Statistical Analysis, Ethics Committee and Ministry of Health Approval}

Statistical Package for Social Sciences Version 21.0 (SPSS v.21.0 for Windows SPSS, Inc., Chicago, IL) was used for all statistical analyses. At the end of the study, the primary endpoint was 50\% reduction in the VASI scores. When parametric assumptions were not provided, lesion diameters and VASI scores were analyzed using Freidman's test. If there was a significant difference, then the Wilcoxon test was used for pairwise comparison. Wilcoxon test results were interpreted according to the Bonferroni-corrected $p$ value. Differences in numeric variables between independent groups were analyzed by using the Mann-Whitney $U$ test when parametric assumptions were not provided. The ci-square test was used to determine whether there were differences in categorical variables between independent groups. Relationships between the quantitative variables were calculated using Pearson's correlation coefficient. For numerical variables which provide parametric test assumptions, intra-group and inter-group differences were analyzed by repeated measures for analysis of variance. The level of statistical significance was set at $p<0.05$.
This study received permission from Hacettepe University Faculty of Medicine Local Ethics Committee Clinical and Pharmaceutical Research on 22.11.2012 (Issue number: 06-03) and also received approval from the Ministry of Health with tracking number 806637 on 24.01.2013.

\begin{tabular}{|c|c|c|c|c|c|c|}
\hline $\begin{array}{l}\text { Number of } \\
\text { patient }\end{array}$ & $\begin{array}{l}\text { Lesion } \\
\text { number }\end{array}$ & Lesion & VASI 0 & VASI 36 & VASI 50 & $\begin{array}{l}\text { Localization } \\
\text { of lesions }\end{array}$ \\
\hline \multirow{4}{*}{$n^{1}$} & \multirow{4}{*}{4} & $\mathrm{~L}^{1}$ & 1.5 & 1 & 1 & Leg \\
\hline & & $\mathrm{L}^{2}$ & 1.4 & 1.2 & 1.1 & Thigh \\
\hline & & $\mathrm{L}^{3}$ & 1.2 & 0.275 & 0.1 & Feet \\
\hline & & $\mathrm{L}^{4}$ & 0.8 & 1.2 & 1.2 & Knee \\
\hline \multirow{4}{*}{$n^{2}$} & \multirow{4}{*}{4} & $\mathrm{~L}^{1}$ & 1 & 1 & 1 & Hands \\
\hline & & $\mathrm{L}^{2}$ & 2 & 1.8 & 1.7 & Hands \\
\hline & & $\mathrm{L}^{3}$ & 0.5 & 0.5 & 0.4 & Hands \\
\hline & & $\mathrm{L}^{4}$ & 1.2 & 1.1 & 1 & Hands \\
\hline$n^{3}$ & 1 & $\mathrm{~L}^{1}$ & 4 & 4 & 4 & Knee \\
\hline \multirow{4}{*}{$n^{4}$} & \multirow{4}{*}{4} & $\mathrm{~L}^{1}$ & 1.125 & 1 & 0.325 & Nape \\
\hline & & $\mathrm{L}^{2}$ & 2.25 & 1.1 & 0.22 & Nape \\
\hline & & $\mathrm{L}^{3}$ & 2.25 & 0.75 & 0.75 & Nape \\
\hline & & $\mathrm{L}^{4}$ & 2.4 & 1.5 & 1.25 & Nape \\
\hline \multirow{2}{*}{$n^{5}$} & \multirow{2}{*}{2} & $\mathrm{~L}^{1}$ & 8 & 7.5 & 8.5 & $\begin{array}{l}\text { Lumbal } \\
\text { region }\end{array}$ \\
\hline & & $\mathrm{L}^{2}$ & 3 & 4.05 & 5 & $\begin{array}{l}\text { Lumbal } \\
\text { region }\end{array}$ \\
\hline$n^{6}$ & 1 & $\mathrm{~L}^{1}$ & 3 & 3 & 4.5 & Nape \\
\hline$n^{7}$ & 1 & $\mathrm{~L}^{1}$ & 3 & 2.79 & 0.8 & Breast \\
\hline \multirow{3}{*}{$n^{8}$} & \multirow{3}{*}{3} & $L^{1}$ & 1 & 0.9 & 1.08 & Back \\
\hline & & $\mathrm{L}^{2}$ & 3.7 & 1.8 & 1.8 & Back \\
\hline & & $\mathrm{L}^{3}$ & 2 & 0.7 & 0.9 & Back \\
\hline \multirow{2}{*}{$n^{9}$} & \multirow{2}{*}{2} & $L^{1}$ & 2 & 2.3 & 2.5 & Feet \\
\hline & & $L^{2}$ & 2.5 & 2.2 & 2.3 & Feet \\
\hline \multirow{4}{*}{$n^{10}$} & \multirow{4}{*}{4} & $\mathrm{~L}^{1}$ & 2.5 & 2.34 & 0.9 & Leg \\
\hline & & $\mathrm{L}^{2}$ & 2.2 & 2.25 & 0.9 & Leg \\
\hline & & $L^{3}$ & 3 & 2.7 & 0.375 & Thigh \\
\hline & & $\mathrm{L}^{4}$ & 3 & 1.6 & 0 & $\begin{array}{l}\text { Sacral } \\
\text { region }\end{array}$ \\
\hline$n^{11}$ & 1 & $L^{1}$ & 2.6 & 3.1 & 3.5 & Hands \\
\hline \multirow{3}{*}{$n^{12}$} & \multirow{3}{*}{3} & $\mathrm{~L}^{1}$ & 2 & 1.5 & 2.25 & Feet \\
\hline & & $L^{2}$ & 2.7 & 3 & 3.6 & Thigh \\
\hline & & $\mathrm{L}^{3}$ & 1.17 & 0.75 & 1.35 & Knee \\
\hline$n^{13}$ & 1 & $L^{1}$ & 2.6 & 2.5 & 2.5 & Knee \\
\hline \multirow{2}{*}{$n^{14}$} & \multirow{2}{*}{2} & $L^{1}$ & 1.95 & 1.875 & 1.875 & $\begin{array}{l}\text { Inguinal } \\
\text { region }\end{array}$ \\
\hline & & $L^{2}$ & 0.825 & 0.45 & 0.675 & $\begin{array}{l}\text { Inguinal } \\
\text { region }\end{array}$ \\
\hline \multicolumn{7}{|c|}{ 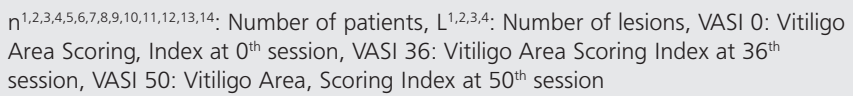 } \\
\hline
\end{tabular}




\section{Results}

Fourteen patients, 10 (71.43\%) female and 4 (28.57\%) male, completed the study. The mean age of the patients was $19.43 \pm 7.39$ years (10-30). Of all, 5 patients had an additional systemic disease including diabetes mellitus $(n=1)$, hypothyroidism $(n=1)$, autoimmune gastritis $(n=1)$, chronic urticaria $(n=1)$, simultaneous occurence of diabetes mellitus, and chronic urticaria $(n=1)$. Three of the patients had a family history of vitiligo in the first or second degree relatives.

A total of 33 lesions from 14 patients were treated (Figure 3). Of these lesions, $5(15.2 \%)$ were localized on the hands, $4(12.1 \%)$ on the feet, $4(12.1 \%)$ on the neck, $4(12.12 \%)$ on the knee, $3(9.1 \%)$ on the thighs, $3(9.1 \%)$ on the legs, $3(9.1 \%)$ on the back, $2(6.1 \%)$ on the inguinal, and $2(6.1 \%)$ on the lumbal region. The remaining 3 lesions were located on the breast, nape and sacral region, respectively. Nine patients had multiple vitiligo lesions. Of these 9 patients, VASI scores of each lesion changed in different proportions during the treatment sessions. All patients received 50 treatments.

Between the $0^{\text {th }}$ and $50^{\text {th }}$ sessions, the mean VASI score of 33 lesions decreased from 2.25 to 1.79 , showing $20.4 \%$ decline (Table 2, Figure 4, $\mathrm{p}<0.05)$. Twenty-one of 33 lesions exhibited a decrease in VASI scores at the end of the $50^{\text {th }}$ session although only 11 of these 21 lesions reached target VASI 50\% while the remaining 10 lesions did not reach the target. As a result, 11 lesions (33.3\%) reached VASI 50\% while the remaining 22 lesions (66.7\%) did not reach the target. Contrarily, in 12 lesions (36.4\%), the VASI score increased $(n=10,30.3 \%)$ or did not change $(n=2,6.1 \%)$. Seven of 12 lesions were located in regions with a high risk of Koebner's phenomenon ( 2 feet, 2 hands, 3 knees). Of these 22 lesions which did not reach the target, microphototherapy

Table 2. Mean Vitiligo Area Scoring Index scores and percentage of VASI decrease of 33 vitiliginous lesions

\begin{tabular}{|l|l|l|l|l|}
\hline Session & $\begin{array}{l}\text { VASI } \\
\text { (Mean } \pm \text { SD) }\end{array}$ & $\begin{array}{l}\text { Session } \\
\text { interval }\end{array}$ & $\begin{array}{l}\text { Percentage of } \\
\text { VASI decrease } \\
\text { (Mean) }\end{array}$ & p score \\
\hline 0 & $2.25 \pm 1.35$ & $0-36$ & 14.2 & $p<0.05$ \\
\hline 36 & $1.93 \pm 1.41$ & $0-50$ & 20.4 & $p<0.05$ \\
\hline 50 & $1.79 \pm 1.76$ & & & \\
\hline \multicolumn{2}{|l|}{ SD: Standard deviation, VASI: Vitiligo Area Scoring Index } \\
\hline
\end{tabular}
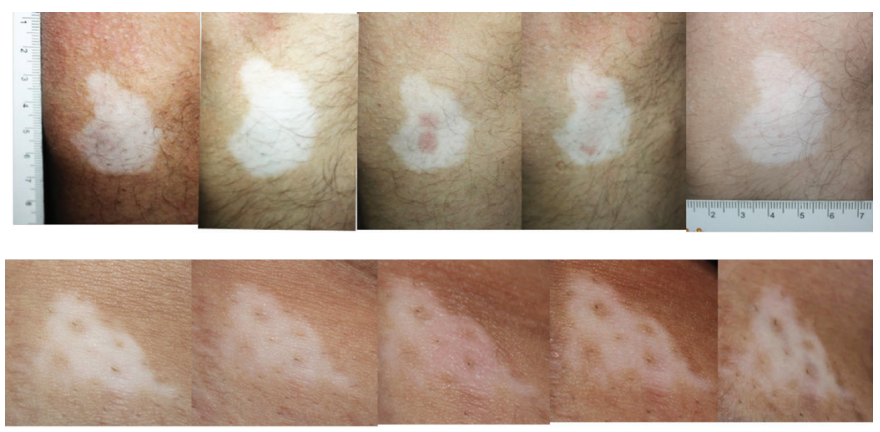

Figure 3. Photos of two different vitiligo lesions taken at treatment $0^{\text {th }}, 12^{\text {th }}, 24^{\text {th }}, 36^{\text {th }}, 50^{\text {th }}$ sessions respectively (The upper lesion seems not to be responsive to the therapy while less than $50 \%$ improvement was recorded in the underlying one). was stopped and the therapy was switched to topical corticosteroid and/or topical immunomodulators. No lesion reached the desired target level before 50 sessions.

Of 33 lesions, in terms of diameter, mean diameter scores decreased from $2.38 \pm 1.35$ to $2.17 \pm 1.68$ showing statistically insignificant decrease at the end of 50 sessions (Figure $5, p=0.322$ ).

The treatment was generally well tolerated except in 3 lesions from 3 different patients of which erythema formation was observed.

\section{Discussion}

To the best of our knowledge, the literature does not include any studies

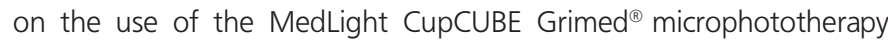
system for the treatment of vitiligo or any other dermatological disease. Several studies have examined the efficacy of UV microphototherapy

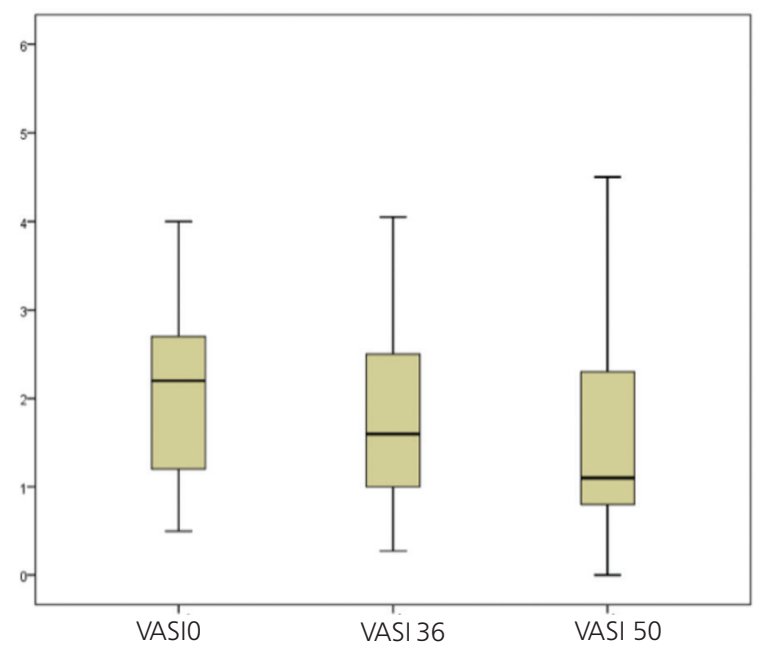

Figure 4. Mean VASI scores at baseline, $36^{\text {th }}$ and $50^{\text {th }}$ sessions in 33 lesions.

(VASIO: Vitiligo Area Scoring Index at session 0. VASI36: Vitiligo Area Scoring Index at session 36. VASI50: Vitiligo Area Scoring Index at session 50)

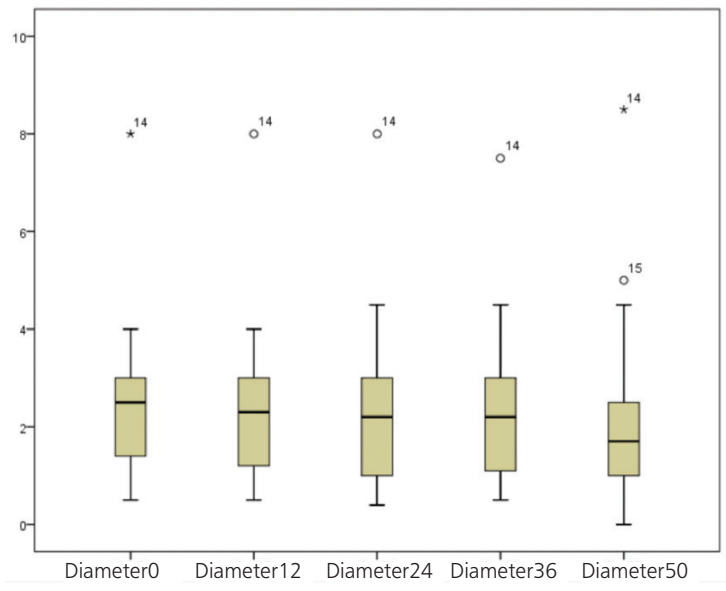

Figure 5. Mean diameter scores at baseline and at $12^{\text {th }}, 24^{\text {th }}, 36^{\text {th }}$ and $50^{\text {th }}$ sessions in 33 lesions.

(Diameter0: Mean diameter at session 0. Diameter12: Mean diameter at session 12. Diameter24: Mean diameter at session 24. Diameter36: Mean diameter at session 36. Diameter50: Mean diameter at session 50). 
for vitiligo, but the findings are inconsistent. Asawanonda et al. ${ }^{4}$ administered irradiation with targeted broad-band UVB phototherapy (Dua-Light ${ }^{\mathrm{TM}}$, TheraLight Inc. Carlsbad, CA USA) in 29 vitiliginous lesions from 6 patients twice weekly for 12 weeks and reported some degree of repigmentation in all subjects with varying responses. In another study, Welsh et al. ${ }^{7}$ achieved improvement using the BClear ${ }^{\circledR}$ UV targeted phototherapy device and UVB irradiation administered twice in a week in 12 patients with vitiligo for 30 sessions. They reported repigmentation from a comparison of baseline photographs with those after 30 sessions by two independent investigators and they concluded that UVB microphototherapy seemed to be effective for the repigmentation of vitiligo in lesions located on the face instead of acral lesions. Akar et al. ${ }^{8}$ declared that despite the fact that the safety of targeted broadband UVB phototherapy in the treatment of localized vitiligo was good, its therapeutic effectiveness was limited and depended on the location of vitiligo lesions.

To increase the efficacy, microphototherapy can be combined with other therapies. Lotti et al. ${ }^{9}$ investigated the effects of topical treatments given alone or in combination with microphototherapy by using a Bioskin ${ }^{\circledR}$ device in patients with vitiligo. 458 patients were divided into 11 groups according to the selected treatment modalities. The researchers reported that targeted combination therapies were prominently more effective than single treatments in vitiligo. When combined therapies were chosen, $0.05 \%$ betamethasone dipropionate cream plus 311 $\mathrm{nm}$ narrow-band UVB (NB-UVB) microphototherapy remarkably gave the highest repigmentation rate. Asawanonda also showed in a study that the combination treatment of targeted NB-UVB phototherapy (DuaLight; TheraLight Inc. Carlsbad, CA, USA) plus 0.1\% tacrolimus ointment was more effective than targeted phototherapy alone for the treatment of patients with vitiligo ${ }^{5}$. Except liquid petrolatum, which is used to increase UV transmission, an additional procedure was not applied in patients in this study. This method, which is used to prevent UV scattering from surface of psoriatic squams, is applied to vitiliginous skin due to the liquid petrolatum's booster effect on UV penetration. Leroy et al. ${ }^{10}$ showed increased penetration of epidermis two-three times following application of vaseline oil to 10 epidermal specimen at the end of 3-minute practice. Similarly in a study by Hoffmann et al. ${ }^{11}$, it was shown that vaseline oil increased UV transmission.

Excimer lasers and excimer nonlasers are the other microphototherapy methods. There are several studies on these devices. The 308-nm laser emits wavelengths adjacent to those of NB-UVB 311-nm phototherapy and presumably may have similar biological and clinical effects ${ }^{2}$. In a study, twice weekly 308-nm excimer laser was given to selected vitiligo lesions for a maximum 60 treatments. The study showed that 308-nm excimer laser allows for fast and targeted treatment and is a beneficial addition to the available treatment options for localized vitiligo, especially for lesions that do not have leukotrichia and are located on the face or proximal extremities ${ }^{2}$. Excimer non-laser sources are also used to treat patients with vitiligo ${ }^{12}$.

Microphototherapy can cause various tolerable adverse effects including erythema, blistering, hyperpigmentation, erosion, burning and itching ${ }^{8,13-16}$. Therefore, in this study, the patients were observed for the occurence of any of these side effects. In patients included in this study, the radiation was generally well tolerated. The observed side effect was erythema formation in 3 of 33 lesions and thus dose escalation was performed until the $50^{\text {th }}$ session in the remaining 30 lesions. Dose escalation was used in order to ensure that as many of the lesions as possible would benefit from the treatment.

The study has some limitations. Firstly, the minimal erythema dose was not calculated. A standard therapy dose and a standard duration of treatment were administered to all patients. Therefore, beginning the treatment with a low UVB dose might have increased the number of sessions. Due to the absence of standard application time, dose and dose escalation for the device, the treatment protocol was identified by the researchers. Having a small number of patients and lacking a control group are the other limitations. Due to the fact that the treatment was time-consuming, laborious, and poorly efficient and it required coming to the hospital thrice weekly, six patients, who initially participated to the treatment apart from our study group of 14 patients, discontinued the treatment. Therefore, in future studies, a larger sample size, higher number of treatments and different therapy protocols are needed.

\section{Conclusion}

The present findings show that the efficacy was poor with targeted UVB radiation by using a MedLight CupCUBE Grimed ${ }^{\circledR}$ microphototherapy device at an emission range of 300-350-nm and a peak of 311-nm with these treatment doses, durations and increments for the treatment of patients with non-segmental, localized vitiligo lesions. This can be explained by the followings; the resistance of vitiligo disease against the treatment modalities, the need for long sessions for acceptable pigmentation, non-use of any photosensitizers to increase the effectiveness of microphototherapy, and the location of lesions with a high risk of Koebner's phenomenon.

Indeed, microphototherapy eliminates unnecessary radiation exposure to large areas of the body, however, this therapy must be administered by experienced technicians/clinicians. Thus, microphototherapy is more expensive and time-consuming than other treatment methods, especially in patients with a lesion $>1 \mathrm{~cm}$ in diameter who require multiple treatment sessions. In addition, microphototherapy requires patients to come to the hospital at least twice a week. As a result of these challenges, we highlight that this technique should be used in patients with vitiligo whose lesions persist despite systemic and topical treatment or when such treatment is contraindicated because of its time-consuming, challenging sides and high cost. Trying topical therapies initially (topical corticosteroids, topical immunomodulators or topical calcipotriol), calculating minimal erythema dose and thus measuring the beginning UV doses and durations as a way to decrease the number of in-hospital sessions are feasible rather than applying this technique as the first option or alone in vitiligo patients with nonsegmental, localized lesions.

\section{Ethics}

Ethics Committee Approval: This study received permission from Hacettepe University Faculty of Medicine Local Ethics Committee Clinical and Pharmaceutical Research on 22.11.2012 (Issue number: 06-03). The present study also received approval from the Ministry of Health with tracking number 806637 on 24.01.2013.

Informed Consent: Consent form was filled out by all participants. Peer-review: Externally and Internally peer-reviewed. 


\section{Authorship Contributions}

Surgical and Medical Practices: N.Y., G.E., Concept: N.Y., G.E., Design: N.Y., G.E., Data Collection or Processing: N.Y., Analysis or Interpretation: N.Y., G.E., Literature Search: N.Y., Writing: N.Y.

Conflict of Interest: We declare that there is no conflict of interest of authors. The manifacturer of the device did not participate in the present study at all such as funding and study design.

Financial Disclosure: The authors declared that this study received no financial support.

\section{References}

1. Mysore V: Targeted phototherapy. Indian J Dermatol Venereol Leprol 2009;75:119-25.

2. Taneja A, Trehan M, Taylor CR: 308-nm excimer laser for the treatment of localized vitiligo. Int J Dermatol 2003;42:658-62.

3. Asawanonda P, Kijluakiat J, Korkij W, Sindhupak W: Targeted broadband ultraviolet $b$ phototherapy produces similar responses to targeted narrowband ultraviolet B phototherapy for vitiligo: a randomized, doubleblind study. Acta Derm Venereol 2008;88:376-81.

4. Asawanonda P, Charoenlap M, Korkij W: Treatment of localized vitiligo with targeted broadband UVB phototherapy: a pilot study. Photodermatol Photoimmunol Photomed 2006;22:133-6.

5. Klahan S, Asawanonda P: Topical tacrolimus may enhance repigmentation with targeted narrowband ultraviolet $\mathrm{B}$ to treat vitiligo: a randomized, controlled study. Clin Exp Dermatol 2009:34:1029-30.
6. Hamzavi I, Jain H, McLean D, Shapiro J, Zeng H, Lui H: Parametric modeling of narrowband UV-B phototherapy for vitiligo using a novel quantitative tool: the Vitiligo Area Scoring Index. Arch Dermatol 2004;140:677-83.

7. Welsh O, Herz-Ruelas ME, Gómez M, Ocampo-Candiani J: Therapeutic evaluation of UVB-targeted phototherapy in vitiligo that affects less than 10\% of the body surface area. Int J Dermatol 2009:48:529-34.

8. Akar A, Tunca M, Koc E, Kurumlu Z: Broadband targeted UVB phototherapy for localized vitiligo: a retrospective study. Photodermatol Photoimmunol Photomed 2009;25:161-3

9. Lotti T, Buggiani G, Troiano M, et al: Targeted and combination treatments for vitiligo. Comparative evaluation of different current modalities in 458 subjects. Dermatol Ther 2008;21(Suppl 1):20-6.

10. Leroy D, Dompmartin A, Deschamps P: Increased penetration of epidermis by high intensity ultraviolet rays following the application of vaseline oil. Photodermatol 1986;3:51-2.

11. Hoffmann K, Kaspar K, Gambichler T, Altmeyer P: Change in ultraviolet (UV) transmission following the application of vaseline to non-irradiated and UVBexposed split skin. Br J Dermatol 2000;143:532-8.

12. Park KK, Liao W, Murase JE: A review of monochromatic excimer light in vitiligo. Br J Dermatol 2012;167:468-78.

13. Lapidoth M, Adatto M, David M: Targeted UVB phototherapy for psoriasis: a preliminary study. Clin Exp Dermatol 2007;32:642-5.

14. Kemény L, Csoma Z, Bagdi E, Banham AH, Krenács L, Koreck A: Targeted phototherapy of plaque-type psoriasis using ultraviolet B-light-emitting diodes. Br J Dermatol 2010;163:167-73.

15. Mudigonda T, Dabade TS, Feldman SR: A review of targeted ultraviolet B phototherapy for psoriasis. J Am Acad Dermatol 2012;66:664-72.

16. Coelho JD, Ferreira A: Letter: Association of targeted intense pulse light system UVA1-UVB and fluticasone in the treatment of vitiligo: Prospective study of 10 patients. Dermatol Online J 2010;16:15 